различным ландшафтам значения варьируют в широких пределах, что связано как с наличием относительно сбалансированных ландшафтов, так и с наличием существенно измененных природных территорий.

Наибольшей антропогенной преобразованности на территории Андроповского района подвергаются Воровсколесско-Кубанский и Прикалаусско-Саблинский ландшафты.

$$
* * *
$$

1. Диденко П. А. Морфологическая и хозяйственная структура лесостепных ландшафтов Ставропольской возвышенности // Вестник Ставропольского университета. - 1999. - Вып. 17. - С. 19-23.

2. Исаков Ю.А. Классификация, география и антропогенная трансформация экосистем / Ю.А. Исаков, Н.С. Казанская, Д.В. Панфилов. -М.: Наука, 1980. - 228 с.

3. Ландшафты Северного Кавказа: эволюция и современность / В. А. Шальнев; науч. ред. А. А. Лиховид; М-во образования и науки Рос. Федерации, Ставроп. гос. ун-т. - Ставрополь: Изд-во Ставроп. гос. ун-т, 2004. - 264 с.

4. Схема использования земельных ресурсов Ставропольского края на агроландшафтной основе до 2005 года. - Ставрополь, 1997. - 11 с.

\title{
Старожилов В.T. \\ Исследования азональных поясов ландшафтной сферы на Дальнем Востоке, в России
}

Тихоокеанский международный ландшафтный иентр ШЕН Дальневосточного федерального университета (Россия, Владивосток)

doi: $10.18411 / \mathrm{j}-02-2021-70$

idsp: ljournal-02-2021-70

\section{Аннотация}

Констатируется, что пример ландшафтных азональных поясов ландшафтной сферы Тихоокеанский ландшафтный пояс (https://doi.org/10.18411/a-2017-089) как основа - модель научного и практического планирования и управления в освоении геосистемы океан- континент ранее не рассматривался. В настоящее время в связи с освоением переходной зоны Азиатского континента к океану появилась необходимость рассмотреть возможности применения ландшафтного подхода в практиках освоения геосистем этой зоны. Работа, представляет собой продолжение комплексных исследований в целом сформировавшейся ландшафтной школы профессора В.Т. Старожилова (doi:10.24411/1728-323X-2020-13079, doi:10.18411/1j-05-2020-26). Отмечается, что комплексное изучение ландшафтного пояса как ландшафтной структуры континентального обрамления Тихого океана, имеет базовое значение при природопользовании зоны перехода от континента к океану. Именно ландшафтный пояс, включающий Сихотэ-Алинскую, Нижнеамурскую, Камчатско-Курильскую, Сахалинскую и другие ландшафтные области представляет собой часть единой с Тихим океаном структуры природы и представляется как основа для выполнения задач науки и практики освоения территорий континентального обрамления Тихого океана и окраинных морей. Он, как планетарная ландшафтная структура, является базовой моделью «фундаментом» для построения гармонизированных с природой и связанных с океаном экологических, сельскохозяйственных и других отраслевых моделей освоения этой обширной тихоокеанской зоны. Отмечается, что в свою очередь применение компьютерной технологии векторно-слоевого ландшафтного метода создают платформу для разработки планов и проектов освоения. Он также является платформой для обучения студентов. Приводятся данные о картографической обеспеченности пояса современными векторно-слоевыми цифровыми материалами.

Ключевые слова: ландшафт, пояс, Тихоокеанский, освоение, океан. 
Abstract

It is stated that the example of landscape azonal belts of the landscape sphere, the Pacific landscape belt (https://doi.org/10.18411/a-2017-089), as a basis - a model of scientific and practical planning and management in the development of the ocean-continent geosystem has not been considered previously. At present, in connection with the development of the transition zone of the Asian continent to the ocean, it is necessary to consider the possibilities of applying the landscape approach in the practice of developing the geosystems of this zone. The work is a continuation of complex research in the whole formed landscape school of Professor V.T. Starozhilov (doi: 10.24411 / 1728-323X-2020-13079, doi: 10.18411 / lj-052020-26). It is noted that a comprehensive study of the landscape belt as a landscape structure of the continental framing of the Pacific Ocean is of basic importance in the use of natural resources in the zone of transition from the continent to the ocean. It is the landscape belt, which includes the Sikhote-Alin, Nizhneamur, Kamchatka-Kuril, Sakhalin and other landscape areas, which is part of the structure of nature united with the Pacific Ocean and is presented as the basis for fulfilling the tasks of science and practice of developing the territories of the continental framing of the Pacific Ocean and marginal seas. It, as a planetary landscape structure, is the basic model "foundation" for building harmonized with nature and related to the ocean ecological, agricultural and other sectoral models for the development of this vast Pacific zone. It is noted that, in turn, the use of computer technology of the vectorlayer landscape method creates a platform for the development of plans and development projects. It is also a platform for student learning. The data on the cartographic provision of the belt with modern vector-layer digital materials are presented.

Key words: landscape, belt, Pacific, development, ocean.

Введение. Пример ландшафтных азональных поясов ландшафтной сферы Тихоокеанский ландшафтный пояс (doi:10.18411/a-2017-089), (https://doi.org/10.18411/a2017-089) как основа - модель научного и практического планирования и управления в освоении геосистемы океан-континент ранее не рассматривался (Рис. 1).

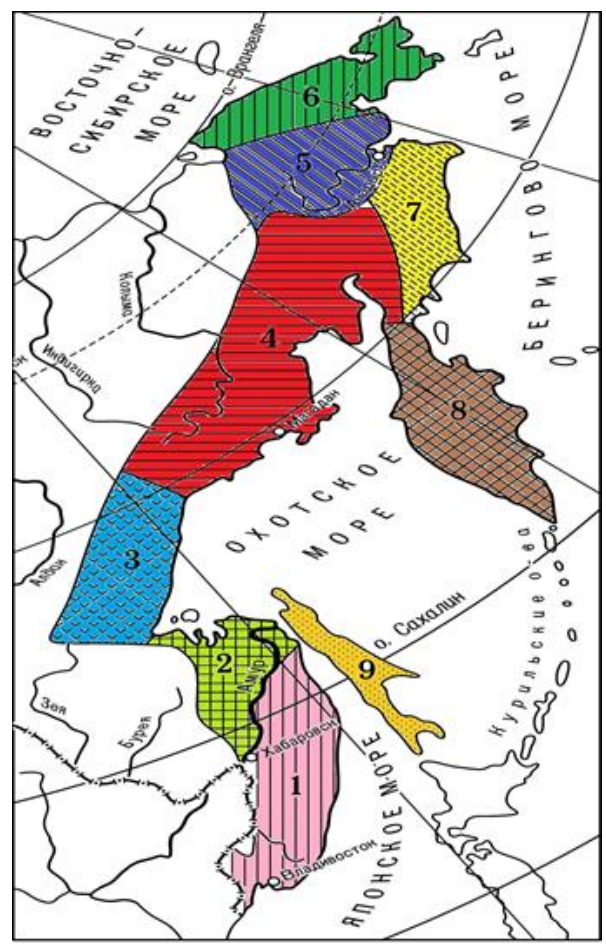

Рис.1. Карта Тихоокеанского ландшафтного пояса России, его областей и окраинных морей (Старожилов, 2018). Области пояса: 1. Сихотэ-Алинская; 2. Нижнеамурская; 3. Приохотская; 4.Кольммкая; 5. Анадырьская; 6. Чукотская; 7. Корякская; 8. Камчатско-Курильская; 9. Сахалинская 
В настоящее время в связи с освоением переходной зоны Азиатского континента к океану появилась необходимость рассмотреть возможности применения ландшафтного подхода в практиках освоения геосистем океан-континент. Работа, представляет собой продолжение комплексных исследований Тихоокеанского международного ландшафтного центра ШЕН ДВФУ, а также в целом сформировавшейся ландшафтной школы профессора В.Т. Старожилова (doi:10.24411/1728-323X-2020-13079, doi:10.18411/1j-05-2020-26) и разработанных парадигм: общей Дальневосточной ландшафтной парадигмы и Дальневосточной ландшафтной парадигмы индикации и планирования (doi:10.18411/1j-05-2020-26), разработок по картографическому оцифрованному ландшафтному обеспечению индикации, планирования и геоэкологического мониторинга юга Тихоокеанского ландшафтного пояса России (doi:10.18411/1j-05-2020-27), а также по «Ландшафтному звену выстраивания планирования и развития экономических, градостроительных и др. структур осваиваемых территорий» (doi: 10.18411/lj-09-2020-36).

Тихоокеанский ландшафтный пояс, представляющий собой уникальную ландшафтную географическую территорию перехода Азиатского континента к океану, играет огромную роль в освоении геосистемы океан-континент. Выделение пояса, как основы-модели природного «фундамента» освоения, это результат нового для России комплексного ландшафтного подхода в понимании зоны перехода континента к океану, основанном на междисциплинарном синтезе, анализе и оценке компонентов его внутреннего содержания (включает фундамент, рельеф, климат, почвы, растительность, биоценозы) [1,3,4]. Он выделен на основе учета взаимодействия, взаимообусловленности и взаимопроникновения друг в друга компонентов, на основе изучения ландшафтов в условиях окраинно-континентальной дихотомии, на основе изучения орогенического, орографического, климатического и фиторастительного взаимодействующих между собой факторов. Комплексное изучение ландшафтного пояса как объемной (с изучением высотного, горизонтального и глубинного его внутреннего содержания) ландшафтной (природной) структуры континентального обрамления Тихого океана, имеет (как структурная ландшафтная единица Земли) базовое значение при природопользовании зоны перехода от континента к океану. Именно ландшафтный пояс, включающий Сихотэ-Алинскую, Нижнеамурскую, Камчатско-Курильскую, Сахалинскую и другие ландшафтные области, как результат взаимодействующих орогенического, орографического, климатического и фиторастительного факторов, с природными границами (что очень важно), представляет собой барьерную структуру зоны перехода континента к океану, фокусом взаимодействия континентальных и океанских ландшафтных структур, особым отражением экзогенных и эндогенных процессов и представляющий в целом объект для освоения его ресурсов. Пояс представляет собой часть единой с Тихим океаном структуры природы и представляется как основа для выполнения задач науки и практики освоения территорий континентального обрамления Тихого океана и окраинных морей (Рис. 1).

Именно азональные пояса, представляют не достающее звено в комплексном изучении Мирового океана. Тихоокеанский ландшафтный пояс представляется конкретным базовым структурным элементом геосистемы океан-континент, объектом комплексной систематизации материалов, планирования, управления освоения окраинной континентальной и морской зоны Тихого океана.

Он, как планетарная ландшафтная структура, является базовой моделью «фундаментом» для построения гармонизированных с природой и связанных с океаном экологических, экономических, социальных, сельскохозяйственных, гидрологических и других отраслевых моделей освоения этой обширной тихоокеанской зоны в геосистеме океан-континент. Однако, на сегодняшний день все еще отсутствуют плановые профессиональные исследования по практикам применения материалов по 
Тихоокеанскому ландшафтному поясу в планировании и управлении освоения геосистемы океан-континент. В целом это и определяет актуальность выполненной работы.

Под ландшафтным поясом понимается - азональный пояс ландиафтной сферы с генетически единым структурно-тектоническим положением в зоне окраинно-континентальной дихотомии системы океан-континент и характеризующегося аккреционной природой фундамента ландиафтных (в Российской части пояса сихотэалинской, ниюнеамурской, приохотской, сахалинской, камчатско-курильской, чукотской и др.) географических областей (структур) с климатическим и растительным внутренним содержанием, подчиняющимся высотной и широтной зональности и эволюционирующим под действием взаимодействующих, взаимосвязанных и взаимопроникающих друг в друга орогенического, орографического, климатического и фиторастительного факторов в определенных зональных и азональных условиях в каэждый момент своего существования.

Цель публикации - обосновать в Российской науке необходимость рассматривать Тихоокеанский ландшафтный пояс как равноценную природную структуру диалектической пары геосистемы континент-океан и обосновать её базовый комплексный характер и как ландшафтную основу-модель при освоении зоны перехода при планировании и проектировании структур освоения системы континент-океан. Ландшафтную модель - пояс рассматривать природным «фундаментом» и основой для построения гармонизированных с природой научных и практик-моделей освоения (экологических, сельскохозяйственных, гидрологических, экономических, социальных, градостроительных и других).

Материалы и методы. Общая методологическая основа исследования ландшафтный подход, в котором ландшафтному анализу подвергаются геосистемы различных рангов и в конечном итоге дается та или иная географическая оценка ландшафтного пространства объекта исследования, а полученные результаты анализа, синтеза и оценки применяются для решения задачи комплексного освоения территорий. С методической точки зрения Тихоокеанских ландшафтный пояс представляет собой часть единой с Тихим океаном структуру природы и представляется как основа для выполнения задач науки и практик освоения территорий обрамления и окраинных морей Тихого океана.

Значимым является то, что в основу выделения пояса, как ландшафтной основы-модели при освоении зоны перехода при планировании и проектировании структур освоения, положены результаты многолетних авторских полевых геологогеографических и географических научных и производственных исследований обширной территории Тихоокеанского ландшафтного пояса России, которые в свою очередь включают полевые исследования Сихотэ-Алинской, Сахалинской, Камчатской, Анадырьской ландшафтных областей $[5,6,9,11,12]$. Важным успехом в их изучении является то, что при выполнении задач ландшафтоведения получен значительный авторский в том числе полевой материал по таким «Наукам о Земле» как геологии, геоморфологии, гидрологии, геохимии, магматизму, вулканизму, полезным ископаемым, климату и др.. Изучались данные не только по рельефу, растительности и почвам, но и коренным и рыхлым породам, климату. Также изучались мощность рыхлых накоплений, транзит обломочного материала, увлажнение, глубина вреза, густота расчленения, интенсивность физического и химического выветривания, мезо- и микроклиматические особенности. Кроме того, исходя из представления значимости всех компонентов и факторов ландшафта, в том числе фундамента как вещественного компонента и фактора его динамики, нами при изучении ландшафтов рассматривается коренной фундамент. Использовались материалы по трансформации ландшафтов под действием различных техногенных воздействий $[2,7,10]$. 
В целом отметим, что весь полученный полевой и научный материал по поясу анализировался на междисциплинарном уровне, осмысливался и формулировался и благодаря этому была определена целостность Тихоокеанского ландшафтного пояса как географической единицы и важность её для выполнения задач освоения обрамления и окраинных морей Тихого океана.

Кроме того, использовались материалы, полученные по итогам многочисленных экспедиций на Сахалине, Камчатке, Чукотке и других территорий Тихоокеанского ландшафтного пояса России:

1. Основы нового в Тихоокеанской России направления географии ландшафтной географии. Она нацелена на практическую реализацию ландшафтного подхода в освоении Тихоокеанской России и на обучение студентами магистрантами программы «Ландшафтное планирование».

2. Основы практической реализации ландшафтного подхода с применением ландшафтной индикации: в лесопользовании Тихоокеанской России; в планировании и проектировании природопользования геосистем.

3. Теория ландшафтной индикации трансформации геосистем Тихоокеанской России.

4. Ландшафтно-природопользовательская стратегия в Тихоокеанской России.

5. Классификация и структурная дифференциация ландшафтных геосистем в масштабах: 1 : 500000 Тихоокеанской России (Сахалинская область, Приморский край); $1: 25000$ - о-ва Русский Приморского края; 1 : 500000 - Сахалинского звена.

6. Методология выделения и внутреннее содержание округов геосистем Сахалино-Приморского региона, Муравьево-Амурского округа (включая о. Русский) Приморского края и иерархическая структура последнего.

7. Методика векторно-слоевого картографирования ландшафтов и выделения округов Тихоокеанского ландшафтного пояса России.

8. Метод векторно-слоевого ландшафтного картографирования и районирования.

9. Концепция индикации ландшафтов Тихоокеанской России.

10. Концепция узловых ландшафтных структур освоения Ландшафтной сферы.

11. Концепция нового структурирования ландшафтных горных и островных систем Тихоокеанского ландшафтного пояса.

12. Концепция высотно-ландшафтных комплексов водосборов юга Тихоокеанского ландшафтного пояса.

13. Концепция высотно-ландшафтных комплексов водосборов островных систем юга Тихоокеанского ландшафтного пояса.

14. Концепция высотно-ландшафтных комплексов озерных водосборов юга Тихоокеанского ландшафтного пояса.

15. Дальневосточная ландшафтная парадигма индикации и планирования.

16. Единая Дальневосточная ландшафтная парадигма.

17. Тихоокеанская ландшафтная парадигма ландшафтных моделей в образовании по «Наукам о Земле».

18. Картографическое (оцифрованное) ландшафтное обеспечение индикации, планирования и геоэкологического мониторинга юга Тихоокеанского ландшафтного пояса России

19. Сихотэ-Алинская область (структура) Тихоокеанского ландшафтного пояса, планирование её освоения и подготовка кадров по «Науки о Земле».

20. Тихоокеанская эколого-ландшафтная парадигма в освоении территорий. 
21. В ДВФУ на базе Тихоокеанского международного ландшафтного центра ШЕН ДВФУ ландшафтной школой профессора В.Т. Старожилова инициирован и создается новый исследовательский и образовательный «Агроландшафтный сектор».

22. Ученые ДВФУ приступили к фундаментальным исследованиям почвенного покрова и ландшафтов заповедников Тихоокеанского ландшафтного пояса.

23. В ДВФУ на базе Тихоокеанского международного ландшафтного центра ШЕН ДВФУ ландшафтной школой профессора В.Т. Старожилова инициирована и предложена стратегия отраслевой (почвоведение) ландшафтной индикации.

24. Агроландшафтные исследования на Дальнем Востоке.

25. Новый агроландшафтный сектор в Дальневосточном федеральном университете.

26. Новая стратегия отраслевой ландшафтной индикации в Дальневосточном федеральном университете.

27. Новые фундаментальные исследования почвенного покрова и ландшафтов заповедников Тихоокеанского ландшафтного пояса.

28. Тихоокеанский ландшафтный пояс как основа-модель практик планирования и управления в освоении геосистемы океан-континент.

При обосновании применения ландшафтного пояса как основы - модели при освоении окраинной переходной зоны к океану использовались материалы практической реализации ландшафтного подхода с применением ландшафтной индикации в различных областях природопользования: при разработке стратегий практической реализации ландшафтного подхода в области туризма и рекреации, градостроительства, организации аграрных предприятий для создания производственной базы в горно-таежных ландшафтах, лесопользавания, планирования и проектирования природопользования.

Использовались также опубликованые профессором В.Т. Старожиловым 350 научных работ, из которых 28 монографий, 25 учебных пособий; 8 ландшафтных карт.

Кроме того особо отметим, что для определения ландшафтной целостности Тихоокеанского ландшафтного пояса, как структурной единицы Земли соизмеримой с фокусом максимального взаимодействия океана и Азиатского континента, применены материалы авторских палеогеографических исследований. Применены результаты геологических и палеогеографических реконструкций по установлению генезиса, состава и тектонической эволюции фундамента пояса. Применялась авторская концепция геодинамической эволюции зоны перехода Азиатского континента к океану [8].

Весь имеющийся материал анализировался на основе сопряженного анализа и синтеза межкомпонентных и межландшафтных связей с учетом окраинноконтинентальной дихотомии и данных по орогеническому, орографическому, климатическому и фиторастительному факторам формирования географически единых территорий. Получены были следующие результаты.

Результаты. При познании, формулировании возможностей и необходимости применения Тихоокеанского ландшафтного пояса как основы-модели в освоении геосистемы океан-континент получен фундаментальный результат настоящих исследований, заключающийся в том, что для реализации рассмотрения планирования и управления освоения пояса, как природной планетарной основы ведения гармонизированных с природой отраслевого освоения, необходимо иметь прежде всего оцифрованную векторно-слоевую морфологическую ландшафтную основу [1]. Такие основы как в целом по поясу, так и по его отдельным регионам получены (Сихотэалинская, Сахалинская и др.). Для реализации поставленных задач получены, прежде всего, оцифрованные векторно-слоевые морфологические ландшафтные модели (векторно-слоевые ландшафтные карты), которые на цифровом уровне дают знание строения географического пространства рассматриваемого объекта. Этот результат 
позволяет проанализировать территории по оцифрованным выделам ландшафтов. Сравнить внутреннее содержание таких таксонов как ландшафт, вид, род, подкласс, класс, тип, округ, провинция, область, пояс. Затем решать задачи по практикам природопользования. Тем более, что результат включает современное компьютерное программное обеспечение.

Синтез, анализ обеспеченности ландшафтного пояса современными векторнослоевыми картографическими материалами, составленными на основе современных требований картографии и математического обеспечения показывает следующую общую картину такой обеспеченности. Составлены карты и объяснительные записки к ним:

1. Карта Тихоокеанского ландшафтного пояса, областей и прилегающих морей в масштабе 1: 3000000 (автор Старожилов В.Т.). На карте также выделены области: Сихотэ-алинская, Нижнеамурская, Приохотская, Колымская, Анадырьская, Чукотская, Корякская, Камчатская, Сахалинская. Представлены сопряженные с областями окраинные моря исследования.

2. Ландшафтная карта Приморского края масштаба 1:1 000000 (автор Старожилов В.Т., сжатая версия электронной карты ландшафтов Приморского края масштаба 1:500 000);

3. Карта ландшафтного районирования Приморского края масштаба 1:1 000 000 (автор Старожилов В.Т.). Выделено 54 округа, 8 провинций, 4 области;

4. На основе базовой карты ландшафтов Приморского края (на карте картографировано 3156 выделов ландшафтов), так как она цифровая, то было получено отдельных 3156 карт по всем выделенным на карте выделам ландшафтов. На основе карты районирования, так как она цифровая векторно-слоевая, то было получено отдельных 66 карт ландшафтных единиц районирования;

5. Впервые для АТР издана (автор Старожилов В.Т.) объяснительная записка к карте ландшафтов Приморского края масштаба 1: 500000 . В ней описано 3156 выделов ландшафтов;

6. На основе основной векторно-слоевой карты ландшафтов Приморского края составлены частные векторно-слоевые карты ландшафтов и высотноландшафтных комплексов островных, озерных и горных водосборов Тихоокеанского ландшафтного пояса, в том числе составлена карта ландшафтов и высотноландшафтных комплексов водосбора озера Ханка;

7. Ландшафтная карта острова Сахалин в масштабе $1: 500$ 000. В настоящее время карта и объяснительная записка к ней готовятся к изданию;

8. Ландшафтная карта урочищ и групп урочищ о. Русский и прилегающих к нему островов Владивостокского городского округа масштаба 1: 25 000;

9. Карта положения и эволюции палеоструктур и сопряженных с ними элементов зоны перехода северо-востока Азии к Тихоокеанской плите.

Карты представляются значимым академическим творением в сфере цифровых карт, основанном на огромном опыте изысканий в области теории, а также практике ландшафтоведения, и вплоть до этих пор в части обзорности и содержательности не имеет аналогов для территории Азиатско - Тихоокеанского региона (АТР), охватывая Азиатские государства. Карты принадлежат к картам новейшего поколения, в которых в перспективе станут отображать в цифровом виде не отраслевые слои компонентов, но слои классификационных единиц ландшафтов. Немаловажно в таком случае то, что карты нацелены на практическую реализацию ландшафтного подхода в освоении земель, а также способны быть применены как естественные модели «фундамент» с целью формирования гармонизованных с природой экологических, гидрологических, экономических, социальных и др. моделей освоения территорий.

Важно отметить, что именно с появлением отмеченных картографических полимасштабных документов появилась возможность анализировать ландшафтные 
модели, сравнивать между собой и рассматривать их природным «фундаментом» и основой для построения гармонизированных с природой различных моделей освоения (сельскохозяйственных, гидрологических, экономических, социальных, градостроительных, краеведческих и других). Такой подход позволит учесть природные условия и технически и юридически обосновать целесообразность предполагаемого освоения ландшафтных территорий.

Однако, как показали исследования Тихоокеанского ландшафтного пояса как основы-модели в освоении геосистемы океан-континент, установление морфологического строения пояса это только первый этап картографирования Тихоокеанского ландшафтного пояса. Специальное изучение фундаментальных направлений картографирования показывает на то, что кроме морфологического направления выделяются: индикационное, ландшафтных узловых структур освоения, планирования и проектирования. Отмечается, что все они сопровождаются составлением векторно-слоевых полимасштабных индикационных, узловых структур освоения, планирования и проектирования векторно-слоевых ландшафтных карт (doi: 10.18411/lj-09-2020-35). Такие работы уже проводятся в Тихоокеанском международном ландшафтном центре ШЕН ДВФУ под руководством профессора В.Т. Старожилова.

Заключение. Итак на Дальнем Востоке, в России под руководством профессора В.Т. Старожилова выделяется Тихоокеанский ландшафтный пояс как основа - модель научного и практического планирования и управления в освоении геосистемы океанконтинент, которая способна решать практические задачи по освоению территорий обрамления и окраинных морей Тихого океана и развитию теоретической базы ландшафтной географии. Выделение пояса это результат нового для России комплексного подхода в понимании зоны перехода континента к океану, основанном на междисциплинарном синтезе, анализе и оценке компонентов его внутреннего содержания (включает фундамент, рельеф, климат, почвы, растительность, биоценозы). Он выделен на основах учета взаимодействия, взаимообусловленности и взаимопроникновения друг в друга компонентов, изучения ландшафтов в условиях окраинно-континентальной дихотомии, изучения орогенического, орографического, климатического и фиторастительного взаимодействующих между собой факторов. Это сделано с использованием цифровых компьютерных технологий. В свою очередь применение компьютерной технологии векторно-слоевого ландшафтного метода создают платформу для разработки планов и проектов освоения. Она также является платформой для обучения студентов.

Разрабатываемое в ДВФУ профессором В.Т. Старожиловым новое для Тихоокеанской России направление понимания зоны перехода континента к Тихому океану и выделение Тихоокеанского ландшафтного пояса как основы - модели, важной для планирования и управления в освоении системы континент-океан, выводит образование, науку и практику на новый информационный и прикладной уровни и позволит его рассматривать как эффективный инструмент планирования и прогнозирования сельскохозяйственных, краеведческих, гидрологических, экономических, социальных, экологических и других геосистем.

$$
* * *
$$

1. Старожилов В.Т. Природопользование: практическая ландшафтная география. / учебник. Школа естественных наук ДВФУ, Тихоокеанского международного ландшафтного центра, Школа естественных наук ДВФУ. Владивосток, 2018. 276с

2. Старожилов В.Т. Эколого-ландшафтный подход в формировании региональной экологической политики на территории стран АТЭС / В сборнике: Шестые Гродековские чтения. Актуальные проблемы исследования Российской цивилизации на Дальнем Востоке. межрегиональная научнопрактическая конференция. Правительство Хабаровского края. Хабаровск, 2009. С. 24-28. 
3. Старожилов В.Т. Региональные компоненты и факторы структуры и пространственной организации ландшафтов юга Дальнего Востока (на примере Приморского края). - Владивосток, 2007.

4. Старожилов В.Т. Ландшафтное картографирование территорий Приморского края // Известия Российской академии наук. Серия географическая. -2010. -№ 2. -С. 82-89.

5. Старожилов В.Т., Зонов Ю.Б. Ландшафтные предпосылки устойчивого развития территорий. / В сборнике: Природа без границ. Материалы I Международного экономического форума. Администрация Приморского края. 2006. С. 261-265.

6. Старожилов В.Т. Ландшафтное районирование Приморского края. Вестник Дальневосточного отделения Российской академии наук. 2010. № 3 (151). С. 107-112.

7. Старожилов В.Т., Леоненко А.В., Крупская Л.Т., Дербенцева А.М. Геоэкология минеральносырьевого природопользования ландшафтов юга Дальнего Востока./ Министерство образования и науки Российской Федерации, Федеральное агентство по образованию, Дальневосточное отделение Российской академии наук, Институт горного дела, Дальневосточный федеральный университет. Владивосток, 2009.

8. Старожилов В. Т. Геодинамическая эволюция зон перехода северо-востока Азии к Тихоокеанской плите / В. Т. Старожилов // Гидрометеорологические и географические исследования на Дальнем Востоке: материалы 5-й юбилейной научн. конф. «К всемирным дням воды и метеорологии». Владивосток, 2004. - С.85-88.

9. Старожилов В.Т. Ландшафтные геосистемы Сахалинского звена окраинно-континентального ландшафтного пояса Тихоокеанской России // Проблемы региональной экологии. - 2016. - № 5. C. 53-57.

10. Старожилов В.Т. Эколого-ландшафтный подход к промышленным территориям юга Дальнего Востока // В сборнике: Современные геофизические и географические исследования на Дальнем Востоке России. материалы 9-й научной конференции, Владивосток: конференция приурочена к Всемирным дням воды и метеорологии, а также к 110-летию ДВГУ и 45-летию ГФФ. Дальневосточный государственный университет, Институт окружающей среды ; под редакцией Н. В. Шестакова. Владивосток, 2010. С. 155-158.

11. Старожилов В.Т. Проблемы ресурсопользования, структура и пространственная организация ландшафтов приокеанских Дальневосточных территорий // В сборнике: Науки о Земле и отечественное образование: история и современность. материалы Всероссийской научнопрактической конференции, посвященной памяти академика РАО А. В. Даринского. Российский государственный педагогический университет им. А. И. Герцена, факультет географии. 2007. С. 310-312.

12. Старожилов В. Т. Ландшафтные геосистемы Сахалинского звена Тихоокеанской России // В сборнике: Научная дискуссия: гуманитарные, естественные науки и технический прогресс. Материалы VII Всероссийской научно-практической конференции. 2015. С. 54-64.

\section{Старожилов В.T. \\ Континентальное обрамление и окраинные моря Тихого океана как планетарная ландшафтная геосистема в освоении мирового океана}

Тихоокеанский международный ландмафтный иентр ШЕН Дальневосточного федерального университета

(Россия, Владивосток)

doi: $10.18411 / 1 j-02-2021-71$

idsp: ljournal-02-2021-71

\section{Аннотация}

Констатируется, что континентальное обрамление и окраинные моря Тихого океана как планетарная ландшафтная геосистема в освоении Мирового океана и выделенные как Тихоокеанский ландшафтный пояс (https://doi.org/10.18411/a-2017089) как основа - модель научного и практического освоения геосистемы океанконтинент ранее не рассматривалась. В настоящее время в связи с освоением переходной зоны Азиатского континента к океану появилась необходимость рассмотреть возможности применения ландшафтного подхода в практиках освоения геосистем этой зоны. Работа, представляет собой продолжение комплексных исследований в целом сформировавшейся ландшафтной школы профессора В.Т. Старожилова (doi:10.24411/1728-323X-2020-13079, doi:10.18411/lj-05-2020-26). 